\title{
A research about job satisfaction of medical secretaries working in a public hospital in the city center of Diyarbakir, Turkey
}

\author{
Rojan Gumus *1, Arif Sahin ${ }^{2}$ \\ ${ }^{1}$ Atatürk Vocational School of Healthcare, Dicle University, Diyarbakir, Turkey \\ ${ }^{2}$ Turkish Statistical Institute, Balikesir, Turkey
}

Received: June 25, 2015

DOI: $10.5430 /$ jha.v4n5p90

\author{
Accepted: July 16, 2015 \\ Online Published: July 24, 2015 \\ URL: http://dx.doi.org/10.5430/jha.v4n5p90
}

\begin{abstract}
Objective: The aim of this study was to investigate the level of job satisfaction among medical secretaries and to identify the major predictors that affect their complaints about work.

Methods: The data were obtained from 115 medical secretaries working in a public hospital. We didn't use any sampling method but tried to reach the whole population in the hospital. As a survey method, Spector Job Satisfaction Survey (JSS, 1985) has been used. JSS is a 36 item, nine facet scale (pay, promotion, supervision, fringe benefits, contingent rewards, operating conditions, coworkers, nature of work and communication) in order to assess employee attitudes about the job and aspects of the job. Its reliability has been measured by the Cronbach Alpha test. Employees were compared according to their gender, age, marital status, education, working status (official-employed by government/ casual staff-employed by firms), working experience (years) and working position (administrative-clinical). Descriptive statistics, significance tests and confidence tests were gained by SPSS 16.0 .

Results: Findings showed that gender and marital status affect satisfaction but age doesn't play a big role. Male participants were more satisfied in terms of promotion $\left(\chi^{2}=27.506, p<.001\right)$ and supervision $\left(\chi^{2}=29.852, p<.001\right)$ facets. In terms of pay $\left(\chi^{2}=15.764, p<.01\right)$, fringe benefits $\left(\chi^{2}=24.948, p<.001\right)$, and contingent rewards $\left(\chi^{2}=26.396, p<.001\right)$ single participants were more satisfied relative to married ones. Also, participants who had working experience over 10 years were more satisfied. The highest significance levels were seen in working position (administrative/clinical) and working status (official-casual). Participants working official and at administrative positions were more satisfied on various facets.

Conclusions: Based on outcomes of this study, it is observed that lowest satisfaction levels were found in pay, promotion, and communication facets. Participants were more satisfied with nature of work, supervision and fringe benefits. Participants working at administrative positions were more satisfied in terms of supervision, coworkers, and nature of work facets. In clinics health workers have more work to do and this may lead to dissatisfaction in relationships with coworkers and supervisors. Because of the fact that working casually means inconsistency of work, hard working conditions, lower payments and impossibility of promotion, participants working casually were dissatisfied in terms of pay, supervision, coworkers, communication and nature of work facets. It is obviously seen that the government has deficiency about describing responsibilities and rights of medical secretaries. The status of work should be strengthened and their future at work should be taken under assurance.
\end{abstract}

Key Words: Medical secretary, Job satisfaction, Spector's job satisfaction survey, Turkey

${ }^{*}$ Correspondence: Rojan Gumus; Email: gumusrojan @ gmail.com; Address: Atatürk Vocational School of Healthcare, Dicle University, Diyarbakir, Turkey. 


\section{INTRODUCTION}

Medical secretaries have a key role among health workers, but this seems to be barely recognized. Sometimes unqualified people take the job who have secretarial skills but lack of medical terminology and health process knowledge. ${ }^{[1]}$ Because of the fact that the role of medical secretaries is very important, besides general hospital practice, they must know aspects of law, ethics, and rights of health workers and patients, and health and safety issues in a clinical environment. ${ }^{[2]}$ They are administrative assistants, that handle and organize reports, histories and accounting. They do a variety of tasks in a hospital or a dental office. Here is an extensive list of things that secretaries do: maintaining records, scanning insurance records, collecting co-payments, checking appointments, assisting with reports, taking histories, arranging hospitalization, ordering surgical supplies, answering phones and greeting patients. Wherever a medical secretary does his/her work, in front or behind, they deal with a lot of paperwork and bureaucracy. ${ }^{[3]}$ Also, another important thing that medical secretaries and doctors share is patient care, so they must work together in order to be more effective. ${ }^{[4]}$ Although they have a key role in the health sector, often they work under hard conditions, and they are not appreciated enough. Their complaints are especially about salary, working conditions and communication at work relative to others having different jobs. In addition, they have complaints about physical symptoms because of work demands, low influence at work and lack of social support. ${ }^{[5]}$ In Turkey, medical secretaries have two real problems: the first one is work definition; what to do and not; the second one is about their working position, being official or casual staff . Turkey's health system gives the right to hospitals to employ health workers as casual staff, while the government employs workers as official staff. This is more preferable because of official rights, higher salaries and consistency of job.

The Ministry of Health in Turkey has been working on a comprehensive health programme in order to strengthen health care management since the early 1990's, but human resource management is still not what it should be. Many of the health care workers have been voicing dissatisfaction with their jobs. ${ }^{[6]}$

Job satisfaction can be defined as "the extent to which people like or dislike their jobs". [7] Job satisfaction is a complex function of a number of variables. A person may be satisfied with one or more aspects of his/her job but at the same time may be unhappy with other things related to the job. Satisfied employees tend to be more productive, creative and committed to their employers. When we look at healthcare organizations, recent studies have shown a direct correlation

Published by Sciedu Press between staff satisfaction and patient satisfaction. ${ }^{[8]}$

Like all jobs, job satisfaction is very important for medical secretaries. It is more crucial for them because what they deal with is human beings and their health. Doctors, dentists, nurses are always appreciated for their work, but it is not the same for medical secretaries. When we look over the literature dealing with job satisfaction among health workers we couldn't find an adequate amount of studies carried out with medical secretaries. In this study, we aimed to measure job satisfaction of a group of medical secretaries working in a public hospital.

\section{METHODS}

In April 2014, we delivered a questionnaire with questions on gender, age, marital status, education, working status (offical-casual staff), working experience (years) and working position (administrative-clinical). This questionnaire was prepared in order to investigate work satisfaction of medical secretaries in a public hospital in Diyarbakır, Turkey. 115 participants completed the questionnaire by the end of April 2014. No sampling methods were used; all of medical secretaries in the hospital took part in this study.

The respondents were requested to complete the Job Satisfaction Survey developed by Paul Spector. ${ }^{[9]}$ The instrument provides sufficient reliability, validity and normative data measurements. The Job Satisfaction Survey, JSS is a 36 item, nine facet scale to assess employee attitudes about the job and aspects of the job. Each facet is assessed with four items and a total score is computed from all items. A rating scale format is used, with six choices per item ranging from "strongly disagree" to "strongly agree". The nine facets included pay, promotion, supervision, fringe benefits, contingent rewards, operating conditions, coworkers, nature of work and communication. ${ }^{[7]}$

All of data have been analyzed by SPSS 16.0. Descriptive statistics such as mean, standard deviation, and percentages were used to describe the studied values. The Chi-square test were used to compare means. Assessment of the facets' internal consistency was measured by the Cronbach $\alpha$ test. Cronbach (alpha) is a coefficient of internal consistency. It is commonly used as an estimate of the reliability of a psychometric test for a sample of examinees. ${ }^{[10]}$ There are different reports about the acceptable values of alpha, ranging from 0.70 to $0.95 .{ }^{[11]}$ In our study we have found a 0.79 Cronbach Alpha coefficient and this is an acceptable value according to the literature.

\section{RESULTS}

The demographics of 115 medical Secretaries are presented in Table 1. Most of participants were female (57\%). The 
highest percentage of participants was the age groups 20-29 $(91 \%)$. More than half of medical secretaries were working at administrative position (55\%), whereas the others were working in clinics $(45 \%)$. The percentage of participants graduated from vocational high school was very high (70\%), others were graduated from high schools. The ratio of working position (official or casual); was nearly equal. Also, the years of service of participants; $>10$ and $<10$ were nearly equal, too.

Table 1. Characteristics of medical secretaries $(\mathrm{N}=115)$

\begin{tabular}{llll}
\hline Variables & & Number & \% \\
\hline \multirow{2}{*}{ Gender } & Female & 66 & 57 \\
& Male & 49 & 43 \\
Age (years) & $20-29$ & 91 & 79 \\
\multirow{2}{*}{ Education status } & $30-55+$ & 24 & 21 \\
& High school & 35 & 30 \\
Marital Status & Vocational high school & 80 & 70 \\
\multirow{3}{*}{ Working Position } & Married & 59 & 51 \\
& Single/divorced & 56 & 49 \\
Working status & Clinical & 64 & 55 \\
& Official & 51 & 45 \\
Working years & $>10$ & 55 & 47 \\
& $<10$ & 60 & 53 \\
\hline
\end{tabular}

Table 2 shows names and item numbers of nine facets of JSS. Table also consists of means and standard deviation of scores due to nine facets.

Table 2. Definitions, item numbers and descriptives of nine facets

\begin{tabular}{llll}
\hline Facet & Item number & Mean & SD \\
\hline 1. Pay & $1,10,19,28$ & 2.87 & 1.181 \\
2. Promotion & $2,11,20,29$ & 3.05 & 1.176 \\
3. Supervision & $3,12,21,30$ & 3.44 & 1.702 \\
4. Fringe benefits & $4,13,22,31$ & 3.36 & 1.279 \\
5. Contingent Rewards & $5,14,23,32$ & 3.09 & 1.308 \\
6. Operating Procedures & $6,15,24,33$ & 3.05 & 1.123 \\
7. Coworkers & $7,16,25,34$ & 3.18 & 1.647 \\
8. Nature of work & $8,17,27,35$ & 4.12 & 1.292 \\
9. Communication & $9,18,26,36$ & 2.77 & 1.195 \\
Total & & 3.214 & 1.322 \\
\hline
\end{tabular}

As shown in Table 2, among nine facets, highest scores of satisfaction was calculated in nature of work, supervision and fringe benefits. The lowest scores were interpreted among pay, promotion, contingent rewards, operating procedures and communication. A total mean score of satisfaction $(3.214 \pm 1.322)$ was found among all facets.

When these nine facets were compared according to gender, age, marital status, education, working status (officialcasual staff), working experience (years) and working position (administrative-clinical) variables, different significance values were gained. Table 3 shows the statistics (chi-square and $p$-values) of participants between nine facets and other demographic variables.

Table 3. Chi-square analysis between demographic variables and JSS facets

\begin{tabular}{|c|c|c|c|c|c|c|c|c|c|c|}
\hline & & Pay & Promotion & Supervision & $\begin{array}{l}\text { Fringe } \\
\text { benefits }\end{array}$ & $\begin{array}{l}\text { Contingent } \\
\text { Rewards }\end{array}$ & $\begin{array}{l}\text { Operating } \\
\text { Procedures }\end{array}$ & Coworkers & $\begin{array}{l}\text { Nature of } \\
\text { Work }\end{array}$ & Communication \\
\hline \multirow{2}{*}{ Gender } & $\chi^{2}$ & 1.864 & 27.506 & 29.852 & 3.908 & 8.092 & 4.601 & 9.488 & 3.948 & 12.512 \\
\hline & $p$ & .868 & $.000^{* * *}$ & $.000^{* * *}$ & .563 & .151 & .466 & .091 & .557 & .028 \\
\hline \multirow{2}{*}{ Age } & $\chi^{2}$ & 3.254 & 14.367 & 10.939 & 3.791 & 9.218 & 1.940 & 14.694 & 8.497 & 12.041 \\
\hline & $p$ & .661 & .013 & .053 & .580 & .101 & .857 & .012 & .131 & .034 \\
\hline \multirow{2}{*}{$\begin{array}{l}\text { Marital } \\
\text { Status }\end{array}$} & $\chi^{2}$ & 15.764 & 2.064 & 7.855 & 24.948 & 26.396 & 4.455 & 3.128 & 4.705 & 2.044 \\
\hline & $p$ & $.008^{* *}$ & .840 & .164 & $.000^{* * *}$ & $.000^{* * *}$ & .486 & .680 & .453 & .843 \\
\hline \multirow{2}{*}{$\begin{array}{l}\text { Education } \\
\text { Status }\end{array}$} & $\chi^{2}$ & 7.202 & 4.268 & 5.338 & 2.861 & 5.189 & 3.134 & 9.023 & 3.417 & 16.847 \\
\hline & $p$ & .206 & .511 & .376 & .721 & .393 & .679 & .108 & .636 & .050 \\
\hline \multirow{2}{*}{$\begin{array}{l}\text { Working } \\
\text { Status }\end{array}$} & $\chi^{2}$ & 22.06 & 9.788 & 30.010 & 3.972 & 3.180 & 33.994 & 44.569 & 7.143 & 36.819 \\
\hline & $p$ & $.001^{* *}$ & .810 & $.000^{* * *}$ & .553 & .672 & $.000^{* * *}$ & $.000^{* * *}$ & .210 & $.000^{* * *}$ \\
\hline \multirow{2}{*}{$\begin{array}{l}\text { Position of } \\
\text { Work }\end{array}$} & $\chi^{2}$ & 19.802 & 10.003 & 23.927 & 25.860 & 3.092 & 5.853 & 14.995 & 57.397 & 23.448 \\
\hline & $p$ & $.001^{* *}$ & .075 & $.000^{* * *}$ & $.000^{* * *}$ & .686 & .321 & .686 & $.000^{* * *}$ & $.000^{* * *}$ \\
\hline \multirow{2}{*}{$\begin{array}{l}\text { Working } \\
\text { Years }\end{array}$} & $\chi^{2}$ & 0.906 & 6.977 & 3.299 & 0.930 & 16.214 & 5.031 & 6.538 & 3.606 & 61.335 \\
\hline & $p$ & .970 & .222 & .654 & .968 & $.006^{* *}$ & .412 & .257 & .607 & $.000^{* * *}$ \\
\hline
\end{tabular}

As shown in Table 3, when nine facets were compared ac- were stratified by gender, a high significance was found in cording to characteristics of participants, different signifi- terms of promotion $\left(\chi^{2}=27.506, p<.001\right)$ and supervision cance values have been interpreted. When the participants $\quad\left(\chi^{2}=29.852, p<.001\right)$ facets. It can be seen that male 
participants are more satisfied relative to female ones.

The test of significance showed that, age affects job satisfaction due to supervision facet. On the other hand, marital status is important in terms of pay $\left(\chi^{2}=15.764, p<.01\right)$, fringe benefits $\left(\chi^{2}=24.948, p<.001\right)$, and contingent rewards $\left(\chi^{2}=26.396, p<.001\right)$. Single participants are more satisfied compared to married ones.

As it can be seen from Table 3, working status is the most important variable in satisfaction. Participants working at official status are more satisfied in terms of pay $\left(\chi^{2}=22.06\right.$, $p<.01)$, supervision $\left(\chi^{2}=30.010, p<.001\right)$, coworkers $\left(\chi^{2}=44.569, \mathrm{p}<.001\right)$, communication $\left(\chi^{2}=36.819\right.$, $p<.001)$ and operating procedures $\left(\chi^{2}=33.994, p<.001\right)$.

According to working position (administrative and clinical) administrative participants are more satisfied in terms of, supervision $\left(\chi^{2}=23.927, p<.001\right)$, nature of work (57.397, $p<.001)$ and, communication $(23.448, p<.001)$ facets. Only due to pay $(19.802, p<.01)$, and fringe benefits $\left(\chi^{2}=25.860\right.$, $p<.001)$ participants working at clinics are more satisfied.

Table 3 shows that, when respondents were compared according to working service of years, medical secretaries working more than 10 years were more satisfied in terms of contingent rewards $\left(\chi^{2}=16.214, p<.01\right)$ and communication $\left(\chi^{2}=61.335, p<.001\right)$.

After interpreting all of findings it can be seen that there is no meaningful significance between other variables in terms of all facets.

\section{DisCussion}

In our study, we evaluated both the global job satisfaction and different dimensions of satisfaction. Based on outcomes of this study, it is observed that the lowest satisfaction levels were found in pay, promotion, and communication facets. Participants were more satisfied with nature of work, supervision and fringe benefits. These finding correspond with a previous study dealing with health workers in a public hospital. ${ }^{[12]}$

When medical secretaries were compared according to gender, we have found that, male participants were more satisfied in terms of promotion and supervision facets. These findings agree with a study done before by health proffesionals. ${ }^{[13]}$ It can be said that there is sex- distinction between male and female participants. Female ones have disadvantage when supervision and promotion is question.

Our findings showed that, age doesn't play a role on satisfaction. This is in aggreement with some previous studies ${ }^{[14-16]}$ but a disagreement with some others. ${ }^{[13,17]}$ They have found

Published by Sciedu Press that younger health workers were more satisfied.

According to our study, single participants are more satisfied in terms of pay, fringe benefits and contingent rewards when compared with married ones. This may occur because of opportunities of extra working hours. These findings conflicts with some previous studies, ${ }^{[13,18]}$ but corresponds with some others. $^{[14,16,17]}$

In our results, medical secretaries working over 10 years were more satisfied in terms of contingent rewards and communication. This finding was consistent with a previous study carried out by health care workers. ${ }^{[18]}$

A substantive significance level was found in working position (administrative/clinical) in terms of nine facets. Participants working at administrative positions were more satisfied in terms of supervision, coworkers, and nature of work facets. This may occur because of some reasons: in clinics health workers have more work to do and this may lead to dissatisfaction in relationships with coworkers and supervisors. Also, in clinics it is very hard to deal with patients, so it can be a factor of dissatisfaction due to nature of work facet. On the other hand this returns to an advantage when pay facet is a question. Having opportunity of extra working hours especially at night enables medical secretaries in clinics earning extra salaries.

The biggest significance levels have been found in statistics done according to working status (official/casual). In Turkey, candidates intending to work as official staff, take an exam named KPSS conducted by the government's Education Ministry. In our study, less than half of participants were examined by KPSS and employed by government. The others were working casually and contracted temporarily by hospital. Working casually means inconsistency of work, hard working conditions, lower payments and impossibility of promotion. So we have found that participants working casually were dissatisfied in terms of pay, supervision, coworkers, communication and nature of work facets. We couldn't find any previous study which compared job satisfaction according to working position and working status similar to ours.

Finally, this study provides information about the status of general job satisfaction of medical secretaries in a public hospital in Diyarbakir, Turkey. Global satisfaction was mean but maximum dissatisfaction was found in payments. Because of the fact that working casually means inconsistency of work, hard working conditions, lower payments and impossibility of promotion, participants working casually were dissatisfied in terms of pay, supervision, coworkers, communication and nature of work facets. It is obviously seen that that the The 
health Ministry of Turkey has deficiency about describing re- work should be strengthened and their future at work should sponsibilities and rights of medical secretaries. The status of be taken under assurance.

\section{REFERENCES}

[1] Andrew RL. In praise of medical secretaries. BMJ. 2003; 327: 99192. http://dx.doi.org/10.1136/bmj.327.7421.991-a

[2] Alexander N. Medical receptionists and Secretaries handbook. Post$\operatorname{grad}$ Med J. 1999; 75: 190. http://dx.doi.org/10.1136/pgmj . $75.881 .190 \mathrm{~g}$

[3] Alis J. Life as a medical secretary-a new learning experience for the aspiring consultant. BMJ. 2003; 326: 403. http://dx.doi .org/1 $0.1136 / \mathrm{bmj} .326 .7385 .403$

[4] Alexander DA. The medical secretary her wievs and attitudes. BJGP. 1981; 31: 368-71.

[5] Larsman L, Kadefors R, Sandsjö L. Psychosocial work conditions, perceived stress, perceived muscular tension, and neck/shoulder symptoms among medical secretaries. Int Arch Occup Environ Health. 2013; 86: 57-63. http://dx.doi.org/10.1007/s0042 $0-012-0744-x$

[6] Eker L, Tuzun EM, Daskapan A, et al. Predictors of job satisfaction among physiotherapists in Turkey. J Occup Health. 2004; 46: 500-505. http://dx.doi.org/10.1539/joh.46.500

[7] Spector PE. Job satisfaction: Application, assesment,causes and consequences. Sage, Thousand Oaks, CA; 1997. 2.

[8] Al-Aameri AS. Job satisfaction and organizational commitment for nurses. Saudi Medical Journal. 2000; 21: 231-35.

[9] Spector PE. Measurement of human service staff satisfaction: Development of the job satisfaction survey. American J of Community Psychology. 1985; 13: 693-713. http://dx.doi.org/10.1007/B F00929796
[10] Cronbach LJ. Coefficient alpha and the internal structure of tests. Psychometrica. 1951; 16: 297-334. http://dx.doi.org/10.10 07/BF02310555

[11] Federal Ministry of Health. Report of the special committee on national health care financing. Lagos: Federal Ministry of Health. 1985.

[12] De Moraes A, Rad AM. Factors affecting employees' job satisfaction in public Hospitals: Implications for recruitment and retention.Journal of General Management. 2009; 34(4): 51-66.

[13] Roopalekha J, Melisha RD, Geena M, et al. Determinants of Job satisfaction among healthcare workers at a Tertiary Care Hospital, Online Journal of Health and Allied Sciences. 2011; 10(3): 1-3.

[14] Butawa NN, Sule AG, Omole VN, et al. Assesment of Job Satisfaction among health Workers in a Tertiary Hospital in Zaria, Northern Nigeria. African Journals Online. 2013; 2(2): 112-119.

[15] Yami A, Hamza L, Hassen A, et al. Job Satisfaction and Its Determinants Among Health Workers in Jimma University Specialized Hospital, Southwest Ethiopia. Ethiopian Journal of health Science. 2011; 21: 19-27.

[16] Bodur S. Job satisfaction of health care staff employed at health centers in Turkey. Occup Med. 2002; 52(6): 353-355. http://dx.d oi.org/10.1093/occmed/52.6.353

[17] Senbounsou K, Mohammad AB, Phathammavong O. Job satisfaction of Health care Workers at health Centers in Vientiane capital and Bolikhamsai Province, Lao PDR. Nagoya J Med Sci. 2013; 75: 233-241.

[18] Top M, Gider O. Interaction of Organizational Commitment and Job satisfaction of Nurses and medical secretaries in Turkey. The International Journal of Human Resource management. 2013; 24: 667-683. http://dx.doi.org/10.1080/09585192.2012.680600 